\title{
Elaborating on ubuntu in a Johannesburg inner-city church
}

\author{
ELINA HANKELA
}

T he article was originally delivered as the speech of the winner of the 2014 Donner Institute

Prize for Outstanding Research into Religion, and deals with some core findings of the research that won the prize, namely, the doctoral thesis Challenging Ubuntu: Open Doors and Exclusionary Boundaries at the Central Methodist Mission in Johannesburg. The author approaches the meanings of ubuntu(Nguni: humanity/humanness) in the context of a Methodist church that sheltered thousands of African migrants in its premises in the inner city of Johannesburg. Using ethnographic research methods, she analyses both the inclusionary message of humanity preached at the church and the exclusionary boundaries between the people who lived in the church and the local congregation that worshipped there. Based on the social dynamics of the church community, the author suggests the rules of reciprocity and survival as some of the socio-moral patterns that set the boundaries to the actualisation of the moral ideal of ubuntuin this context. Overall, the case of this particular church speaks to a broader discussion of the meaning of and limits to being human in one world.

'Have you heard that there is xenophobia in Balfour in Mpumalanga?' Freedom, ${ }^{1}$ a Zimbabwean teenager, asked me in February 20 Io. ${ }^{2}$ I had known Freedom for some months already, and thus I also knew that he was not only referring to xenophobic attitudes, but, rather, to violent attacks on black African migrants. I had met Freedom in inner-city Johannesburg, at the Central

1 The names of the informants, apart from Paul Verryn, have been changed.

2 Elina Hankela was awarded the 2014 Donner Institute Prize for Outstanding Research into Religion. This article is an edited version of her speech delivered at the prize ceremony, which took place during the Donner Institute Symposium 'Religion and Food' at Åbo Akademi University on 25 June 20r4. It is based on the book Ubuntu, Migration and Ministry: Being Human in a Johannesburg Church (Brill 2014); some sections of this text have previously been published as part of the book. For the full manuscript of the book, see <http://www.brill.com/products/book/ubuntumigration-and-ministry>. Moreover, some sections of this text have been previously published as part of the article 'Rules of reciprocity and survival in negotiating Ubuntu at the Central Methodist Mission in Johannesburg'(Hankela 2013). 
Methodist Mission (CMM), where he used to stay like hundreds of his compatriots. At the time, however, Freedom was staying in Soweto, and so I asked him if he was afraid of 'it' also coming to Soweto. 'Not now', he responded, 'but after the FIFA World Cup'. Freedom seemed to think that the interest of the world in the 2010 host country of the soccer spectacle would protect him against xenophobic violence for the time being.

When I first met Freedom I was conducting fieldwork at the CMM for my doctoral thesis. In this article, I first introduce the CMM, that is, the context of the research project, and then briefly touch upon questions related to methodology and the ubuntu (Nguni: 'humanity, humanness') discourse that features as my theoretical framework. I end by making some remarks about ubuntu in the context of the CMM.

\section{Context: The Central Methodist Mission, Johannesburg}

The CMM is established in a six-storey church building in inner-city Johannesburg. In 2009 it was both host to a large Methodist congregation and a shelter for a shifting population of two to three thousand international migrants and homeless South Africans. ${ }^{3}$ I will call the first group members and the latter dwellers. Approximately 90 per cent of the dwellers, like Freedom, came from Zimbabwe. His story resonates with a collective narrative of his compatriots who due to the economic and political meltdown in their country have headed abroad; by far the largest percentage migrating to neighbouring South Africa, and in particular Johannesburg - the City of Gold, or the city of dreams of a better life; often a city of dreams deferred. Those who had ended up at the CMM lived in the church building; they slept in overcrowded rooms and foyers, on stairs and floors. Some parts of the church resembled a squatter camp; and some informants dubbed the building a refugee camp. The members of the congregation, on the other hand, were predominantly South African, the

3 According to an estimate made by the African Centre for Migration and Society, there were I.7 million foreign-born residents in South Africa in 2009 ( $4 \%$ of the population) (cf. Landau et al. 2010). In 2008 I.25 million Zimbabweans 'legally' crossed the border to South Africa; in 2000 the figure was approximately half a million. In other words, migration between Zimbabwe and South Africa has increased in the $2000 \mathrm{~s}$ (cf. Crush and Tevera 20Io). Yet it is important to note that both officials and the media have exaggerated the number of undocumented migrants (and undocumented Zimbabweans) in South Africa (cf. Landau et al. 20ro; on estimations by the public and the media of the number of Zimbabweans in South Africa, see Crush and Tevera 2010; Makina 2010). 
majority of them Xhosas. However, there were foreign nationals among them, too. The members came to the CMM, as any local church community would, to worship.

While Freedom's comments on xenophobia are one window on the discussion of the issue in South Africa at large, there was also tension and separation between the members and the dwellers at the CMM. Unathi, a young member, for instance, said: 'There is a church where we worship; (and) there is a church that provides accommodation for refugees' ${ }^{4}$ The focus of my research project was on the dynamics of and the socio-moral meanings attached to the relationship between these 'two CMM's': the local members and the largely foreign dwellers. This is where I discuss the meaning of ubuntu.

By 2009, the CMM had changed tangibly as a church after having opened its doors some years earlier to asylum seekers and other homeless people under the aegis of the Ray of Hope Refugee Ministry. While this church has a history of social and political engagement, the recent spatial transformation can still be described as radical. A South African Methodist theologian, Neville Richardson (2007: I I4) wrote of the CMM in a 2007 article as 'an almost unrecognizable church, a church that exists not for itself but for others, a witness to Christ the man for others, the crucified Christ'. The building had indeed been 'crucified'. For example, its glass door had been broken, toilets had been blocked and a journalist at some stage called the church 'a haven for criminals' (Moeng 2009). There is, however, another side to the coin: different skills training programmes continue to be run in the building; both a primary and a high school operate under the umbrella of the CMM and in 2009 there was still a Doctors without Borders clinic operating at the church - and so on.

Some aspects of the transformation of this once middle-class church into a 'refugee camp' resonate with the transformation of the surrounding city space. The inner city itself has changed from being the number one business centre in the area into what Martin Murray (20I I: I49) describes as an outcast ghetto; that is, 'a territorially stigmatized place that operates as a site of spatial confinement and control over those with no place in the city'. Not unlike the CMM, the inner city has come to be known for its abandoned buildings inhabited by homeless squatters. The area seems to feature as one huge 'crime hotspot' in the imagination of those Jo'burgers who never venture to this part of the city. However, the inner city that I got to know in 2009 was not merely an outcast ghetto, but rather a domain of different and contrasting layers of reality. For instance, lawyers work in the high court right next to the CMM. They have 
coffee in a cosy coffee shop catering for them in an area which is otherwise characterized by fast food outlets. ${ }^{5}$ Overall, questions related to socio-economic inequality and poverty are topical in the inner city in general, and along with the Refugee Ministry these issues have become incarnate within the sacred space at the CMM.

\section{Methodology: ethics through ethnography}

Initially I ended up in the inner city because of my interest in understanding the encounters between African migrants and churches in South Africa. I was a doctoral student in social ethics who found I could not take on the question by the means of the method of a close reading of texts which is characteristic of my discipline. Hence I signed up for methodology courses in the department of anthropology. Later, when reading Christian Scharen and Aana Marie Vigen's book Ethnography as Christian Theology and Ethics (201 I), I found a name for what I was doing: social ethics through ethnography; wanting to join in 'an attempt to give social ethics an empirical dimension' (Glover I 999: x).

I spent roughly a year doing fieldwork at the CMM conducting interviews, hanging out at the church, attending meetings and services, recording sermons, volunteering as a youth group facilitator and so on. I ended up with transcribed interviews, sermons and field notes as my primary data. The praxis cycle model served to structure the research project. The praxis cycle is influenced by liberation theologies and thus underlines a close connection between theory and practice, between social scientific tools and socio-ethical reflection, and between the agency of the researcher and that of the researched. The steps of the model that I paid the most attention to in my project are 'identification' (e.g. asking questions such as: Who am I? Who are the people I engage with?), 'social analysis' of the context and 'theological/ethical reflection'. 6 For the purposes of my project, I fine-tuned the model by adding aspects of grounded theory and by applying insights gained during my background training as a systematic theologian.

It was missiologists from the University of South Africa who first introduced me to the praxis cycle which they commonly use at their department. I was thus provided with an avenue along which to pursue my research not only on South Africa, but also in South Africa - in dialogue with colleagues at the

5 On the city's attempts to 'regenerate' the inner city, see e.g. Winkler 2013.

6 On the praxis cycle, see e.g. Hankela 2014a, Wijsen et al. 2005, Kritzinger 2002, Holland and Henriot $9_{98} 3$. 
University of South Africa, where I furthermore spent a year after the year of fieldwork, as a visiting researcher. With hindsight, I see the importance of this 'being in South Africa' aspect more clearly than what I understood to be the case at the time. Being together with South African scholars did not, of course, remove me from my social location - that of a white European researcher - but it gave me a chance to learn about my limits as well as my strengths, some of which are tangibly related to my social location.

\section{Theoretical framework: ubuntu discourse}

During my fieldwork 'humanity' and 'relationship' emerged as being the recurrent core categories in understanding the encounter between this particular local church and migrants. The 'grounded' focus of the analysis then directed my choice of the academic ubuntu discourse as a theoretical framework.

The Nguni term ubuntu could be translated into English as 'humanity' or 'humanness'. The academic discourse that scrutinizes this notion introduces an ethic of interdependence. Human beings are thought to exist only through other human beings. Virtues commonly attached to ubuntu include respect, hospitality and compassion, and are generally expected to actualize in concrete relationships. ${ }^{7}$ Desmond Tutu, the world-renowned Anglican leader, writes:

A person with Ubuntu is open and available to others, affirming of others, does not feel threatened that others are able or good, for he or she has a proper self-assurance that comes from knowing that he or she belongs in a greater whole and is diminished when others are humiliated and diminished when others are tortured and oppressed. (Tutu r 999, quoted in Gathogo 2008: 48)

The academic contributions to an understanding of ubuntu vary significantly in scope and in how they approach the notion. Some discuss ubuntu primarily as a political idea, others concentrate on its cultural roots, yet others apply it in various academic fields. Michael Eze's (2010) interpretation impacted on my work. Eze manages to bridge the gap between those who treat ubuntu as an ideal of the pre-colonial past, something that de facto structured social life in the African village of the past, and those who argue that it is merely a recent political construct created by an elite. Eze (2010: I6I, I 84-5) speaks of ubuntu as an 
open-ended 'historical process' and emphasizes its differing manifestations and modes in different times and contexts.

In my research I then observed ubuntu as a local process in the context of the CMM. For me, the dynamics in South Africa between frequent references to ubuntu by politicians, clergy and advertisers (cf. Shutte 200 I: I4), on the one hand, and widespread xenophobic attitudes (cf. Hassim et al. 2008; Nyamnjoh 2006: 38-9), on the other, call for reflections on what it means to be human in contemporary communities. And so did the tense relationship between the members and the dwellers at the CMM. Ethnographic research on the grassroots meanings and relevance of ubuntu has not played an important role in academic discourse; hence my attempt to make a contribution in that area.

\section{Ubuntu at the CMM 1: the theological vision}

In thinking of ubuntu at the CMM, one place to begin is the leader of the church, the Superintendent Minister Paul Verryn, and his vision of humanity. In 2009 Verryn also still served as the district bishop. He was by far the most influential actor at the CMM as Andile, a long-term member, illustrated: '[What is] central at Central? The bishop. He is central at Central but ... I'm afraid 'cause Central is him. If he goes, where do we stand as Central? ... The refugees, I would say he is the father to the refugees. ${ }^{8}$ As a bishop and superintendent minister, Verryn was in a position to create space for his vision at the CMM - by opening the doors of the church.

Sunday after Sunday he preached about an inclusionary humanity - much in line with Tutu's words quoted above - to members in the morning and dwellers in the evening. Verryn would, for instance, talk about the barriers people build between themselves, and say: 'God has no clue of who's who in the zoo. He has no idea unfortunately about DRC people, Zimbabwean, South African. All God sees is humanity.' Or he would remind the dwellers of their inherent dignity and potential: 'We want everybody in this building to understand that they are made in the image of God - even if they are at the back of the queue.'

Although Verryn barely used the Nguni term ubuntu, I called his vision a Christian contextual ubuntu vision in my study. The main reason for this is the strong resonance between various aspects of his thinking and the broader discourse - which I don't have the space to discuss in more detail here. But also,

8 Interview conducted by the author in Johannesburg on I 2.6.2009.

9 Sermons preached at the CMM by Verryn on 5.4.2009 and 14.6.2009 respectively.

Recorded by the author. 
when I asked Verryn what ubuntu is, his response was: humanity. It is clear that the term 'humanity' as Verryn used it is a broader concept than ubuntu, but what ubuntu as an ethical maxim stands for is key to understanding his thinking on humanity.

Moreover, Verryn's interpretation of what it means to be human was influenced by a liberation-theological framework, or, by an engagement with the social context and with the liberating potential of humanity in that context. ${ }^{10}$ As with Desmond Tutu's 'ubuntu theology', in Verryn's thinking and ministry, too, an ethic of ubuntu has been brought into dialogue with other thought systems. His preaching did not seek to capture an authentic essence of ubuntu, but rather sought to understand what ubuntu could do in people's lives and in their relationships with each other in the context of socio-economic inequality and xenophobia.

Looking at the expression of Verryn's thinking as one voice that participates in the discussion of ubuntu in the South African public sphere exposes the contextual and multifaceted nature of any moral discourse. In Johannesburg, ubuntu and the meanings attached to being human are being negotiated in a multilingual, multicultural, multi-social-class, post-apartheid context - and through his praxis, Verryn has participated in the discourse as a Methodist, English-speaking, white, South African male.

If we then think of the role and relevance of ubuntu in grassroots communities, Verryn's preaching indicates that the notion has an important place, at least at the level of discourse. From this perspective, those scholars who imply that the contemporary emphasis on ubuntu is primarily due to a political nationbuilding agenda do not do justice to the ethos of grassroots communities such as the CMM.

\section{Ubuntu at the CMM 2: the relationship between the members and the dwellers}

This ethos was the reason for the dwellers to be at the CMM and for the existence of the relationship between them and the members. Hardly anyone at the church would have disagreed with Verryn's vision of humanity, but its material manifestation in the Refugee Ministry raised opposition among the members. It was the tension between Verryn's tireless preaching on inclusive humanity and the exclusionary boundaries that characterized the encounters between members and dwellers that caught my attention time and again. In a 
sense, ubuntu challenged the community at the CMM, but was also constantly being challenged by the community. As a researcher I then asked: What limits, and what enables, the actualization of ubuntu in the relationship between the members and the dwellers? And what do these dynamics expose about being human - or humane - and about ubuntu?

Three sets of issues emerged in the dwellers and members' narratives as causes for the exclusionary boundaries: first, dirt and disrespectful behaviour, second, experiences and narratives of xenophobia, and third, issues related to management and lack of agency. I will make a few references to people's experiences of these matters as a background to what I say about the negotiation of ubuntu in this location.

\section{Dirt and disrespectful behaviour}

Many members were uncomfortable with the lack of cleanliness, especially when they saw it as a consequence of the dwellers' deliberate actions. Thobeka said:

[The relationship] is not good at all, I must not lie. Because the people of the church, they look at these people [the dwellers] as people who have vandalized their church, as people who are making their church filthy, as people who are doing all those bad thing, bad activities in the church which they respect. ${ }^{11}$

While the daily discomfort was definitely a factor in the unhappiness among the members, at a deeper level many felt that the dwellers affected the status of the CMM as a local church negatively.

\section{Experiences and narratives of xenophobia}

In the dwellers' narrations, on the other hand, xenophobia was a common point of reference. Xenophobia was not only a name for their experiences in South Africa at large but also for the tense situation at the CMM. Prince, for instance, gave the following narrative account:

So now they [the members] are calling that church their church. But Church is for everybody, you know. So, if you find, if you find that xeno-

11 Interview conducted by author in Johannesburg on 3.6.2009. 
phobia is starting in the Church, so who's going to like encourage people not to do such things? It's starting from the Christians. ${ }^{12}$

As much as the collective narrative was based on personal experiences, it also made individual dwellers withdraw from interacting with members even if they had never had negative experiences themselves. In this way the narrative became a tool with which to negotiate the dwellers' position at the CMM - a church whose leader's ethos rendered the preferential option to the marginalised.

\section{Management and lack of agency}

Lastly, a number of members expressed their discontent with the decisionmaking and the day-to-day management of the Refugee Ministry. According to Andile, the ministry had initially started on an ad hoc basis, by Verryn responding to people's need for accommodation. Andile said:

It started by a few people who needed accommodation. Then they came in numbers. Then it became out of control. And the bishop took it to the leaders meetings that we have these people and we are doing it temporarily.... But they said it's his own baby. ${ }^{13}$

'Out of control' and 'his own baby' describe the sense many members had of the ministry.

An ethnographic analysis of the dynamics that I have briefly introduced here plays a big role in my dissertation: these narratives are the basis on which I build the socio-moral patterns which characterize the situation. In other words, my reflection on the moral universe is a result of my taking a step further away from the data, and from my ethnography and, as Juliet Corbin and Anselm Strauss (2008: 56) would put it, 'hypothesizing about the relationships between concepts'.

\section{Ubuntu at the CMM 3: socio-moral patterns}

On the basis of my ethnographic engagement with the CMM, both members and dwellers cherished relational virtues and had expectations towards

12 Interview conducted by author in Johannesburg on 20. I I.2009.

13 Interview conducted by author in Johannesburg on I 2.6.2009. 
other people that were very similar to the ones Verryn preached about. In theory, both groups agreed on the ethical core of his vision. A set of relational virtues - such as recognition, respect, care and help - marked the direction of the communities' moral maps. But as has become clear by now, the actualization of the virtues in the interaction between the groups was constantly contested. Scholars have spoken of ubuntu as 'being-with-others' (Louw 200I: I 5) and argued that 'a person's humanity' is 'discovered and recognized through good relations and interactions with others' (Munyaka and Motlhabi 2009: 74). At the CMM however the humanity of the two groups was hardly discovered in this given relationship.

The actualization of ubuntu was limited - but also enabled - by various socio-moral patterns. These include structural elements, some internal to the CMM, others characteristic of the inner city in general. Moreover, the patterns include what I called limiting rules. Here I concentrate on these rules of reciprocity and survival.

Notions such as a demand for reciprocity or self-survival have not been central in the academic discourse on ubuntu, but they appeared to be central to the grassroots dynamics of the CMM. This might be partly due to the fact that the patterns that emerged out of my fieldwork are based on a situation where the interaction between two large groups was already tense. The academic discourse on ubuntu, on the other hand, often concentrates on relationships between persons and a community, of which the person in question is, is not, or could be a part.

The rule of reciprocity points at a clear expectation that the other group should behave in a way that is worthy of our group's practise of ubuntu. If only they kept the building clean. ... If only they did not hate foreigners... . In this sense, humanness did not only appear to be characterized by interdependence, as often emphasized by ubuntu scholars, but humane conduct emerged as being somewhat dependent on the receiving end. The case of the CMM suggests that my embracing of the other is only required after they embrace me. It seems that the rule of reciprocity might have been a central undertone in the dynamic because the relationship was characteristically one between two relatively large groups; embracing a misbehaving group appears to be a much bigger challenge than embracing an ill-disciplined individual. From this perspective the CMM situation helps one to understand the friction between various social groups in contexts similar to that of inner-city Johannesburg and this church, despite the communal values that might be held by people in these contexts. On the other hand, however, the expectation of reciprocity actually acknowledges the other 
as a human being who is capable of practising ubuntu and has the potential to participate in humane relationships.

The rule of reciprocity is closely linked to the rule of survival. Briefly put, this rule indicates that when one's own existence or group identity is at risk, one may compromise ubuntu, and maybe even should. The deteriorating state of the church building brought about anxiety among church members: was the sacred space turning into 'a social purgatory' or 'an urban hellhole', as Martin Murray (2OII: I 52) describes the perceptions that people have of the innercity residential neighbourhoods of Johannesburg? I was told that a number of members had left the church because of the Refugee Ministry. The Ministry probably supported Verryn's liberation-theological identity, but it did not seem to support the religious identity of many members due to the attached sense of a threat to their existence as a (certain kind of a) Christian congregation. This rule, too, underlines interdependence: if the humanity of one party - here the human needs and the agency of the members - is not respected, that party is consequently released from the duty to practise ubuntu.

The case of the CMM exposes both the importance of the notion of ubuntu in people's thinking and the difficulties in embracing this, or any, moral ideal. While in the academic discourse having or expressing ubuntu is often presented as a prerequisite for being a person, at the CMM, by contrast, compromising ubuntu in this given relationship at times emerged as a means of defending one's own group's human dignity. Nevertheless, this moral compromise featured as a moral burden to many.

\section{(Not) final words}

The former president of the Republic of South Africa, Thabo Mbeki (2005), proposed that a task team should 'elaborate on [ubuntu's] value system and suggest the manner in which we can use it to define ourselves as South Africans'. If this proposal is to be pursued, not only the values ought to be elaborated on. In order to make a difference in society, we should also continue to elaborate on the ways in which the values are de- and reconstructed and contextualized in local communities, and on the socio-moral patterns that delineate the playing field of an ubuntu ethic.

Elina Hankela, ThD (2013, University of Helsinki), is a postdoctoral research fellow affiliated with the University of Helsinki (Department of Theology) and the University of South Africa (Research Institute for Theology and Religion). She is a member of an international comparative research project that focuses on faith-based organizations, social cohesion and marginalized youth. 


\section{References}

Bailie, John, 2009. 'The impact of Liberation Theology on Methodism in South Africa with regard to the doctrine of Christian perfection. Diss. University of South Africa, <http://uir.unisa.ac.za/bitstream/handle/I0500/2600/thesis_bailie_j. pdf> (accessed I 9.I I.2014)

Corbin, Juliet, and Anselm Strauss, 2008. Basics of Qualitative Research: Techniques and Procedures for Developing Grounded Theory, 3rd edn (Los Angeles, SAGE)

Crush, Jonathan, and Daniel Tevera, 2010. 'Exiting Zimbabwe' in Zimbabwe's Exodus: Crisis, Migration, Survival, ed. Jonathan Crush and Daniel Tevera (Cape Town, SAMP), pp. I-49

Eze, Michael Onyebuchi, 2o ro. Intellectual History in Contemporary South Africa (New York, Palgrave Macmillan)

Gathogo, Julius, 2008. 'African philosophy as expressed in the concepts of hospitality and ubuntu', Journal of Theology for Southern Africa, I 30, pp. 39-53

Glover, Jonathan, I 999. Humanity: A Moral History of the Twentieth Century (New Haven, Yale University Press)

Hankela, Elina, 2013. 'Rules of reciprocity and survival in negotiating ubuntu at the Central Methodist Mission in Johannesburg', Journal of Theology for Southern Africa, I47, pp. 73-89

-2014a. Ubuntu, Migration and Ministry: Being Human in a Johannesburg Church (Leiden, Boston, Brill)

-20r4b. "We're not liberated yet in South Africa": Liberation Theology and the concept of humanity in inner-city Johannesburg', Religion and Theology, 2 I, pp. I $73^{-206}$

Hassim, Shireen, Tawana Kupe, and Eric Worby (eds), 2008. Go Home or Die Here: Violence, Xenophobia and the Reinvention of Difference in South Africa (Johannesburg, Wits University Press)

Holland, Joe, and Peter Henriot S. J., I 983. Social Analysis: Linking Faith and Justice (Maryknoll, Orbis Books, in collaboration with Washington, DC, Center of Concern)

Kritzinger, J. N. J., 2002. 'A question of mission - a mission of questions', Missionalia, 30(I), pp. I44-73

Landau, Loren, Tara Polzer, and Aurelia Wa Kabwe-Segatti, 20 Io. 'The mobile nation: how migration continues to shape South Africa' in New South African Review 1. 2010: Development or Decline?, ed. John Daniel, Prishani Naidoo, Devan Pillay, and Roger Southall (Johannesburg, Wits University Press), pp. 2 I 8-35

Louw, Dirk J., 200r. 'Ubuntu and the challenges of multiculturalism in post-Apartheid South Africa', Quest, I $5(\mathrm{I}-2)$, pp. I 5-36

Makina, Daniel, 20 го. 'Zimbabwe in Johannesburg' in Zimbabwe's Exodus: Crisis, Migration, Survival, ed. Jonathan Crush and Daniel Tevera (Cape Town, SAMP), pp. 225-4I 
Mbeki, Thabo, 2005. 'Address of the President of South Africa, Thabo Mbeki, on the occasion of the Heritage Day celebrations, Taung, North West Province', 24.9.2005, <http://www.info.gov.za/speeches/2005/050926 I 2 I 5 I $004 . h t m>$ (accessed I 2.9.20I I)

Metz, Thaddeus, 20r 2. 'An African theory of moral status: a relational alternative to individualism and holism', Ethical Theory and Moral Practice, I 5 (3), pp. 387-402

Moeng, Katlego, 2009. 'Church now a haven for criminals', Sorvetan, I6.7.2009, <http://www.sowetanlive.co.za/sowetan/archive/2009/o7/r6/church-now-ahaven-for-criminals?filter=all_comments $>$ (accessed IO.I I.20 I4)

Munyaka, Mluleki, and Mokgethi Motlhabi, 2009. 'Ubuntu and its socio-moral significance' in African Ethics: An Anthology of Comparative and Applied Ethics, ed. Munyaradzi Felix Murove (Scottsville, University of KwaZulu-Natal Press), pp. $63-84$

Murray, Martin, 20 I I. City of Extremes: The Spatial Politics of Johannesburg (Durham, Duke University Press)

Nyamnjoh, Francis B., 2006. Insiders and Outsiders: Citizenship and Xenophobia in Contemporary Southern Africa (Dakar, CODESRIA)

Richardson, Neville, 2007. 'Sanctorum Communio in a Time of Reconstruction? Theological pointers for the Church in South Africa', Journal of Theology for Southern Africa, I 27, pp. 96-I I 5

Scharen, Christian, and Aana Marie Vigen (eds), 20I r. Ethnography as Christian Theology and Ethics (London, Continuum)

Shutte, Augustine, 200 I. Ubuntu: An Ethic for a New South Africa (Pietermaritzburg, Cluster)

Tutu, Desmond, I 999. No Future without Forgiveness (New York, Doubleday)

Wijsen, Frans, Peter Henriot, and Rodrigo Mejía (eds), 2005. The Pastoral Circle Revisited: A Critical Quest for Truth and Transformation (Maryknoll, Orbis)

Winkler, Tanja, 20r 3. 'Why won't Downtown Johannesburg "regenerate"? Reassessing Hillbrow as a case example', Urban Forum, 24, pp. 309-24 